\title{
Influence of the Shock Absorbers Type Change at Stress of the Trolleybus Chassis
}

Pavel Polach

Section of Materials and Mechanical Engineering Research, Výzkumný a zkušební ústav Plzeň s.r.o., Tylova 1581/46, 30100 Plzeň. Czech Republic. E-mail: polach@vzuplzen.cz

ŠKODA VÝZKUM cooperated on the development of the NEOPLAN DMA low-floor articulated trolleybus intended for the Boston city (the United States). Multibody models and finite element models of the trolleybus were utilized in the stage of the vehicle design. The multibody models of the trolleybus were created in the alaska simulation tool and the simulations were especially aimed at determining forces acting in the trolleybus suspension elements and radius rods. At the end of the stage of computer modelling and testing the trolleybus prototype a decision to change the type of shock absorbers used in the axles' suspension was made. The impact of this change on forces acting in the trolleybus suspension elements (i.e. in air springs and shock absorbers) and radius rods on the trolleybus chassis when running on an uneven test track was investigated using multibody simulations. Time histories of the forces calculated utilising multibody models were used as input data of the trolleybus finite element models. Stress in the critical places of the trolleybus body structure was determined utilizing the finite element models.

Keywords: Trolleybus, Shock absorber, Multibody model, Dynamics, Constructional design

\section{Acknowledgement}

The paper has originated in the framework of institutional support for the long-time conception development of the research institution provided by Ministry of Industry and Trade of the Czech Republic.

\section{References}

[1] ANDERSSON, D., ERIKSSON, P. (2004). Handling and ride comfort optimisation of an inter-city bus. In: Vehicle System Dynamics, Supplement, Vol. 41, pp. 547 - 556. Taylor \& Francis.

[2] BLUndell, M., HARTY, D. (2004). The Multibody Systems Approach to Vehicle Dynamics. Elsevier Butterworth-Heinemann, Oxford.

[3] CHAlUPA, M., SEVERA, L., VLACH, R. (2011). Vehicle Track Loading Simulation. In: Proceedings of The 4th International Conference on Machine Vision (ICMV 2011), Vol. 8349, No. 1, pp. 1 - 5. SPIE - The International Society for Optical Engineering, Singapore.

[4] CHALUPA, M., VLACH, R. (2013). Simulation of vehicle track dynamic loading. Proceedings of international conference Engineering mechanics 2013 (I. Zolotarev, (Ed.)), pp. 67 - 68. Institute of Thermomechanics AS CR, v.v.i.,, Svratka.

[5] ELS, P.S., UYS, P.E., SNYMAN, J.A., THORESSON, M.J. (2006). Gradient-based approximation methods applied to the optimal design of vehicle suspension systems using computational models with severe inherent noise. In: Mathematical and Computer Modelling, Vol. 43, No. 7 - 8, pp. 787 - 801. Elsevier.

[6] ERIKSSON, P., FRIBERG O. (2000). Ride comfort optimisation of a city bus. In: Structural and Multidisciplinary Optimisation, Vol. 20, No. 1, pp. $67-75$. Springer.

[7] GENTA, G., MOREllo, L. (2009). The Automotive Chassis. Volume 2: System Design. Springer Science+Business Media B.V.

[8] GILlESPIE, T. D., KARAMIHAS, S. M. (2000). Simplified models for truck dynamic response to road inputs. In: International Journal of Heavy Vehicle Systems, Vol. 7, No. 1, pp. 52 - 63. Inderscience Publishers.

[9] HEGAZY, S., RAHNEJAT, H., HUSSAIN, K. (1999). Multi-body dynamics in full-vehicle handling analysis. In: Proceedings of the Institution of Mechanical Engineers, Part K: Journal of Multi-body Dynamics, Vol. 213, No. 1, pp. 19 - 31. SAGE Journals.

[10] HEGAZY, S., RAHNEJAT, H., HUSSAIN, K. (2000). Multi-Body Dynamics in Full-Vehicle Handling Analysis under Transient Manoeuvre. In: Vehicle System Dynamics, Vol. 34, No. 1, 2000, pp. 1 - 24. Taylor \& Francis.

[11] HOLEČEK, M., POLACH, P. (1998). Study of the influence of shape of road surface unevenness on vehicle dynamic response. Research Report VYZ 0165/98. ŠKODA RESEARCH Ltd., Plzeň. (in Czech) 
[12] KOWARSKA, I., SKARBEK, J., KUCZEK, K., UHL, T. (2011). Model-based engineering - simulations based design of the suspension of city bus. In: Journal of KONES Powertrain and Transport, Vol. 18, No. 4, pp. 205 212. Institute of Aviation. Poland.

[13] MAIßER, P., WOLF, C.-D., KEIL, A., HENDEL, K., JUNGNiCKEL, U., HERMSDORF, H., TUAN, P., A., KIELAU, G., ENGE, O., PARSCHE, U., HÄRTEL, T., FREUDENBERG, H. (1998). alaska, User Manual, Version 2.3. Institute of Mechatronics, Chemnitz.

[14] MARGOLIS, D., EDEAL, D. (1989). Modeling and Control of Large Flexible Frame Vehicles Using Bond Graphs. SAE Technical Paper 892488. Society of Automotive Engineers, Warrendale.

[15] MICHELBERGER, P., KERESZTES, A., BOKOR, J., VARIAKI, P. (1984). Dynamic Modelling of Commercial Road Vehicle Structures from Test Data. SAE Technical Paper 845120. Society of Automotive Engineers, Warrendale.

[16] POLACH, P. (2004a). Multibody Models of the NEOPLAN DMA Low-floor Articulated Trolleybus and Simulations of Selected Operational Situations for FEM Calculations. Research Report VYZ 0689/2004. ŠKODA VÝZKUM s.r.o., Plzeň.

[17] POLACH, P. (2004b). Verified multibody model of the empty low-floor articulated NEOPLAN DMA trolleybus, results of simulations of running over the large road unevenness and study calculations. Research Report VYZ 0718/2004. ŠKODA VÝZKUM s.r.o., Plzeň. (in Czech)

[18] POLACH, P. (2004c). Verified Multibody Model of the Empty NEOPLAN DMA Low-floor Articulated Trolleybus and Results of Running over the Large Road Unevenness Simulations. Research Report VYZ 0726/2004. ŠKODA VÝZKUM s.r.o., Plzeň.

[19] POLACH, P. (2013a). Utilization of Multibody Simulations at the American Trolleybus Development. In: Proceedings of 11th International Conference Dynamics of Rigid and Deformable Bodies 2013 (J. Skočilasová, (Ed.)), CD-ROM. Jan Evangelista Purkyně University in Ústí nad Labem, Ústí nad Labem.

[20] POLACH, P. (2013b). Utilization of Multibody Simulations at the Trolleybus Development. In: Manufacturing Technology, Vol. 13, No. 4, pp. 515 - 520. Jan Evangelista Purkyně University in Ústí nad Labem, Ústí nad Labem.

[21] POLACH, P. (2014). Influence of the Shock Absorbers Type Change at Stress of the American Trolleybus Chassis. In: Proceedings of 11th International Conference Dynamics of Rigid and Deformable Bodies 2014 (J. Skočilasová, (Ed.)), CD-ROM. Jan Evangelista Purkyně University in Ústí nad Labem, Ústí nad Labem.

[22] POPP, K., SCHIEHLEN, W. (2010). Ground Vehicle Dynamics. Springer-Verlag, Berlin Heidelberg.

[23] RIDEOUT, D. G. (2012). Simulating Coupled Longitudinal, Pitch and Bounce Dynamics of Trucks with Flexible Frames. In: Modern Mechanical Engineering, Vol. 2, No. 4, pp. 176 - 189. Scientific Research Publishing Inc.

[24] ŘEHOŘ, P., KEPKA, M., KOTAS, M., VÁCLAVÍK, J., FRÉMUND, J. (1998). Operating Test of the ŠKODA 14Tr San Francisco Trolleybus on a Test Track. Research Report VYZ 0204/98. ŠKODA RESEARCH Ltd., Plzeň.

[25] SMOLA, M., JANKOVEC, J., HEJMAN, M. (2004). Static and Dynamic FEM Calculations of the NEOPLAN DMA Low-floor Articulated Trolleybus. Research Report VYZ 0693/2004. ŠKODA VÝZKUM s.r.o., Plzeň.

[26] THORESSON, M.J., UYS, P.E., ELS, P.S., SNYMAN, J.A. (2009). Efficient optimisation of a vehicle suspension system, using a gradient-based approximation method, Part 1: Mathematical modelling. In: Mathematical and Computer Modelling, Vol. 50, No. 9 - 10, pp. 1421 - 1436. Elsevier.

[27] VALÁŠEK, M., KORTÜM, W., ŠIKA, Z., MAGDOLEN, L., VACULÍN, O. (1998). Development of semi-active road-friendly truck suspensions. Control Engineering Practice, Vol. 6, No. 6, pp. 735 - 744 . Elsevier.

[28] VLK, F. (2000). Dynamics of motor vehicles. VLK Publishing House, Brno. (in Czech)

[29] SRAC (1999). COSMOS/M, Finite Element Analysis System, User Guide, Version 2.5. SRAC, Los Angeles. 